\title{
An Analysis of Proposed Framework on Impact of Working Capital Management on the Profitability of Selected Manufacturing Companies Listed on the Nigerian Stock Exchange
}

\author{
Yusuf Aminu*, Nasruddin Zainudin \\ Universiti Utara Malaysia, Malaysia \\ *aminukaura2011@gmail.com
}

\begin{abstract}
Working capital management encompasses the overall idea of management of current assets and current liabilities of a business. Whether empirical or conceptual, the discussion have delineated working capital management as that part of business strategy which involves effective management of short term or current assets and liabilities to ensure optimal level and maximization of value. This paper aims to provide an analysis on the concept and propose framework that emphasizes on investigating the impact of management of working capital on the profitability of manufacturing companies listed on the Nigerian stock exchange. The paper proposes four dimensions (variables) as cash management levels, inventory management levels, receivable management, and the trade credit (Accounts payable) as measures of working capital management and the profitability of companies.
\end{abstract}

Keywords: Management of working capital, inventory management, receivables management, and profitability

\section{Introduction}

Literature relating to corporate finance and accounting have centered mostly on long-term financial decisions, mainly on investment, capital structure, dividends or company valuation decision. However, needless to say that short-term assets and liabilities are important components of total assets and therefore needs to be analyzed (Talat and Nazir, 2011). In view of their importance, there is the need for careful and systematic investigation of these short term assets and liabilities, since they play a vital role for firm's profitability, risk as well as its value (Smith 1980). Efficient and effective management of working capital is an important component of overall corporate strategy to create value for the business. Companies always attempt to maintain an ideal stage of working capital that maximizes their value (Howorth and Westhead, 2003, Deloof 2003, Afza and Nazir, 2007).The working capital management, therefore encompasses the overall idea of management of current assets and current liabilities. The importance of working capital management is reflected in the fact that financial managers spend a great deal of time in managing current assets and outstanding. Making arrangement for quicker financial solutions, obtaining an ideal term of credit, ensuring smooth cash operation, making sure receivables accounts are collected at the right time and ensuring an acceptable inventories level constitute the routine roles of financial managers (Prasana, 2000). In manufacturing firm's large portion of assets are composed of current assets, so management of capital and its importance is unquestionable. How working capital is managed affects the liquidity and profitability (Raheman and Nasr, 2007). Excellence management of working capital decreases the dependence on external financing due to more internal flow of cash, which decreases the possibility of failure in an organization (Deloof, 2003). The manufacturing sector in Nigeria, for a number of years has been witnessing a high production costs, which eventually reduces profitability. Akinbuli (2006) posits that poor management of current assets and current liabilities were the major causes of business failure in Nigeria. Therefore, there is a strong conviction that, there is the need to intensify research on this ever-lingering effective management of working capital globally and especially in a developing economy like Nigeria's, where little has been done so far, and little has so far been achieved.

\section{Literature Review}

Working capital management is very crucial in this period of global financial turmoil (Uremadu, Egbide and Enyi, 2012). Efficient working capital management would seek to strike a balance between having too high and too little liquidity to achieve an optimal level (Zainudin 2006). Peavler (2009) as cited in Uwuigbe, Uwalomwa, and Egbide (2012) observed that up to $60 \%$ of failed business emanates from cash problem 
(Which is an integral part of the working capital management. In line with this, however, the declines in profitability of most firms and business today have been largely attributed to poor and ineffective management of working capital. Various studies and researches have been conducted to determine the relationship between working capital management and profitability. Shin and Soenen (1998) utilized a sample of 58, 985 firm years for periods 1975-1994 to investigate the relationship between net trade cycle which was used to measure the efficiency of working capital management and corporate profitability. They found a negative relationship between the length of the firm's net trade cycle and its profitability. Deloof (2003) examined the relationship between working capital management and profitability for a sample of 1,009 Belgian non-financial firms. The relationship was found to be negative. He measured the profitability by the gross operating income, and working capital management by the cash conversion cycle. Lazaridiz and Tryfonidis (2006) studied the relationship between working capital management and profitability of listed companies in the Athens stock exchange. The relationship was found to be positive. They measured gross operating profit and the cash conversion cycle. Raheman and Nasr (2007) selected a sample of 94 Pakistani firms listed on Karachi Stock Exchange, for period covering 1999-2004. A negative relationship was also established. Ali (2011) explores the association between working capital management and the profitability of textile firms in Pakistan. Return on assets was found negatively related to average days receivable. Drawing from the above and other numerous studies undertaken in the area of working capital management and corporate profitability, the findings have always been inconsistent and still needs revalidation. More so, there is still a dearth of literature on studies that examine the relationship between all the components of working capital management and corporate profitability especially in the manufacturing sector of developing economy like Nigeria.

\section{Concept of Working Capital Management}

Working capital management involves the management of the current assets of the firm and the appropriate financing for those assets. It simply involves financing and controlling the current assets of the firm (Stanley and Geoffrey, 1997). It could equally be viewed as management of current assets. To fully understand the concept of working capital it is necessary to appreciate some basic elements build-up there in. Working capital management simply denotes short term assets used in the operations of a business. While the net working capital is defined as current assets minus current liabilities. Net operating working capital (NOWC) is defined as operating current assets minus operating current liabilities. Generally, NOWC is equal to cash, accounts receivable, and inventories less accounts payable and accruals (Brigham \& Micheal, 1999).

The Working Capital Cash Flow Cycle: The concept of the cash flow cycle is important in working capital management. This cycle can be described for a typical manufacturing firm as follows:

- The firm orders and then receives the raw materials it needs to produce the goods it expects to sell. Since firms usually purchase their raw materials on credit, this transaction creates an account payable.

- Labor is used to convert the raw materials into finished goods. To the extent that wages are not fully paid at the time the work is done, accrued wages therefore build-up.

- The finished goods are sold, usually on credit, which creates receivable no cash has been received yet.

- At some point during the cycle, accounts payables and accruals must be paid. This usually occurs before the receivables have been collected, and at that point, a net cash drain which requires financing occurs.

- The working capital cash flow cycle is completed, when the firm's receivables have been collected. At that point, the firm is ready to repeat the cycle and pay the loans that were used to finance it. (Brigham and Houston, 2007).

The Cash Conversion Cycle Model: Richards and Laughlin (1988) developed a useful approach to analyzing the working capital cash flow cycle. Their approach centers on relating operating event to cash flows, and it is called the cash conversion cycle model. Here are some terms used in the model. Inventory conversion period; which is the average length of time required to first convert raw materials into finished goods and then to sell these goods. It might take, on average, 50 days from receipt of raw materials to manufacture and then sell the finished product. 
$\mathrm{ICP}=$

365

Sales/inventory

Receivables conversion period: which is the average Length of time required to convert the receivables into cash. That is, to collect cash following a sales. Payable deferral period: which is the length of time between the purchase of raw materials and the cash payment for them? That would be 30 days if the firm buys on 30-day term and pays on time. Cash conversion cycle; which is the length of time between actual cash expenditures on Productive resources (raw material and labor) and actual cash receipts from the sale of products, that is, from the day labor and /or suppliers are paid to the day receivables are collected (Brigham and Houston, 2007). Therefore, the cash conversion cycle is represented below:

$\mathrm{ICP}+\mathrm{RCP}-\mathrm{PDP}=\mathrm{CCC}$

The Cash Management Levels: Most businesses are conducted regionally, nationally or even globally. Manufacturing companies operate through the head offices to branches, stores via the supply chains. Therefore an integral part of working capital management is the effective cash management level, which includes a system of transfer of funds from where they come in, to where they are needed, depending on where it is lacking and where it is in excess (Brigham and Micheal, 1999).To most of us 'cash' conventionally means coins and paper money including deposits in the bank. In contrast the financial experts simply refer it to currency, deposits demand, and securities that are easily convertible at a predictable price and thus be converted to bank deposits. Therefore, "cash" as reported on balance sheets generally includes short-term securities, which are also called "cash equivalents". Demand (or checking) deposits are far more important than currency for most business. These deposits are used for transactions. The following levels are used to optimize demand deposits holdings.

Inventory Management Levels: Mostly in manufacturing company's inventory usually comprises of raw materials, work in progress, other supplies and final products. All these forms of inventory need to be financed and their efficient management can increase a firm's profitability. (Stanley and Geoffrey, 1997).Optimum inventory levels depend on sales, so sales must be forecasted before target inventories can be established. Moreover, because errors in setting inventory levels lead to lost sales or excessive carrying costs, inventory management is quite important. Therefore, firms use sophisticated computer systems to monitor their inventory holdings. (Brigham and Houston 2007).Although inventory management may be considered as outside the main stream of finance, it is however necessary to emphasize its importance and potential effects to corporate profitability of manufacturing companies.

Accounts Receivable Management: Firms would in general, rather sell for cash than on credit, but competitive pressure force firms allowing credit. By giving these goods out and reducing the stock an account receivable is created. Receivables management begins with guideline on credit, and to put a check on the system is equally vital. Corrective actions are mostly required, more so, the only means of understanding if the condition is getting out of hand is with good receivable control system (Brigham \& Michael, 1999).

Credit Policy: A credit policy consists of the following four (4) variables: ( Brigham and Houston, 2007).Credit period: is the length of time buyers are given to pay for their purchases for example, the credit period might be 30 days. Customers prefer longer credit periods, so lengthening the period will stimulate sales. However, long credit periods lengthen the cash conversion cycle, hence ties up more capital in receivables and that is costly. Also, the longer a receivable is outstanding, the higher the probability that the customer will default and the account will end up as a bad debt (Brigham \& Houston, 2007).

Discounts: They are price reductions given for early payment. The discount specifies the percentage reduction and how rapidly payment must be made to be eligible for the discount. For example, a 2 percent discount might be given if the customer pays within 10 days. Offering discounts has two benefits. First, the discount amounts to a price reduction and lower prices stimulate sales. Second, discounts will cause some customers to pay earlier than they otherwise. Would, which will shorten the cash conversion cycle. However, discount mean lower prices, hence lower revenues unless the quantity sold increases by enough to offset the price reduction. The benefits and costs of discounts must be balanced if a rational decision about them is to be made. 
Credit standards refer to the required financial strength of acceptable credit customers. Factors considered here would be ratios like the customer's debt and interest coverage ratios, Credit history (has the customer paid on time in the past, or tended to be delinquent), and the like. In essence, what is the likelihood that the customer will be willing and able to pay off the Receivable on schedule? Note that if standards are set too high the firm will lose sales and thus profit. Thus a balance must be struck between the costs and benefits of tighter credit standard.

Collection policy: refers to the procedures used to collect past due accounts, including the toughness or laxity used in the process. At one extreme, the firm might write a series of polite letters after a fairly long delay, while at the other extreme delinquent accounts would be turned over to a collection agency relatively quickly. Some firmness should be used, but excessive pressure can lead basically good customers take their business elsewhere. Again a balance must be struck between the costs and benefits of different collection policies (Brigham \& Houston, 2007).

Monitoring Accounts Receivable: The total amount of accounts receivables outstanding at any given time is determined by the volume of credit sales and the average length of time between sales and collections. Receivable account $=$ a day sales on credit $\mathrm{X}$ collection period in days

If either credits sales or the collection period changes, so will accounts receivables. If Management is not careful the collection period will creep up, as good customers take longer to pay and as sales are made to weaker customers, who tent to pay slowly or not at all, and thus accounts will become bad debts. So it is important for manufacturing companies to monitor receivables. The techniques for such monitoring are: ACP or Day sales outstanding is a measure of the average length of time it takes customers to pay for their credit purchases. And it can be compared with the industry average.

$$
\text { DSO }=\frac{\text { Receivables }}{\text { Annual sales } / 365}
$$

Aging schedules: It is a device of breaking down the receivables by age of account.

Accounts Payable (Trade Credit): Manufacturing firms generally make purchases from other firms on credit and record the debt as accounts payable. Accounts payable, is the biggest item in the classification of short term debt. This credit is a spontaneous source of financing in the sense that it arises spontaneously from ordinary business transactions.

Profitability: Earning a profit is the fruit of a business. It indicates how well a business or company is performing. It measures the success of the business. A company or business may not be performing in some important aspect but once it generates profits other inadequacies are ignored. Profitability reflects the final result of good operations of business. Rate of return ratios and profit margin ratios are the main categories of profitability ratios. The relationship between profit and sales is measured by profit margin ratios. Net profit and gross profit margin ratios are the two profit margin ratio. While the relationship between investment and profit is measured by rate of return ratios. Other measures of rate of measures are return on total assets, earning Power, and return on equity (Prasana, 2000).

Gross margin ratio profit is

Gross profit

Gross profit is the difference between net sales and cost of goods sold.

It shows the margin left after meeting manufacturing costs. Efficiency of production and pricing are measured using this ratio.

Profit margin ratio (net): is

Net profit

Net sales

This ratio shows the earnings left for shareholders (both equity and preference) as a percentage of net sales. It measures the overall efficiency of production, administration, selling, financing, pricing and tax 
management. These ratios helps in understanding the firm's cost and profit structure in order to appreciate level of resources utilization.

Return on total assets; is:

\section{Net income (profit)}

Average total assets

That net income to total assets ratio is supposedly a measure of how efficiently the capital is Employed (Demirguc and Huizinga, 2012).

Earning power: is a measure of operating profitability. The earning power is defined as:

Earnings before interest and taxes

Average total assets

The earning power measures business performance which is not affected by interest Charges and tax payments. It takes away the effects of financial structure and tax rate and focuses on operating performance.

Return on Equity: a measure of interest to equity owners, the ROEIs defined as:

Equity Earnings

Average net worth

The numerator of this ratio is equal to profit after tax less dividends. The denominator includes all contributions made by equity shareholders (paid-up capital + reserves and excesses). It is also called the return on net worth. It measures, the profitability of equity funds invested in the firm.

\section{Research Framework}

As a result of the diverse literature reviewed the following variables shall be used for this study:

- Company's Profitability (Dv): Measured by gross operating profit and return on total assets. This is line with previous studies (Wang, 2000).

- Intervened (Mediated): Optimum operating cycle as intervened variable, this was suggested by (Nobenee, 2012) that an optimum operating cycle may be used as an additive function. It simply helps in assessing the ideal level of inventory conversion period plus the optimal length of receivable collection period. Lazaridis and Tryfonidis, (2006) state that the optimum level of inventories will have a direct effect on profitability since it will raise working capital resources which in turn will be converted into business cycle.

\section{- Independent Variable (IV)}

$\checkmark$ Comprehensively measured by the Cash Conversion Cycle (CCC). Many studies have adopted the CCC as a measure of working capital management (Deloof, 2003; Gill, Biger, \& Mathur, 2010; Lazaridis \& Tryfonidis, 2006).

$\checkmark$ Inventory conversion period is a component of cash conversion cycle. This variable was used by (Deloof, 2003; Lazaridis \& Tryfonidis, 2006).

$\checkmark$ Receivable conversion period (measured through average collection period) is a component of CCC it was a variable in studies like (Lazaridis \& Tryfonidis, 2006; Talat \& Nazir, 2011; Wang, 2000).

$\checkmark$ Account payable (Payable deferral period) as a component of CCC was used as a variable in many studies such as (Deloof, 2003; Gill et al., 2010).

$\checkmark$ Current asset to total asset ratio (CATAR) this variable was used by (Nor ediazhar, Noriza, 2010).

$\checkmark$ Current liabilities to total asset ratio (CLTAR). This is another independent variable used in the study of (Nor ediazhar, Noriza, 2010). 


\section{Research framework}

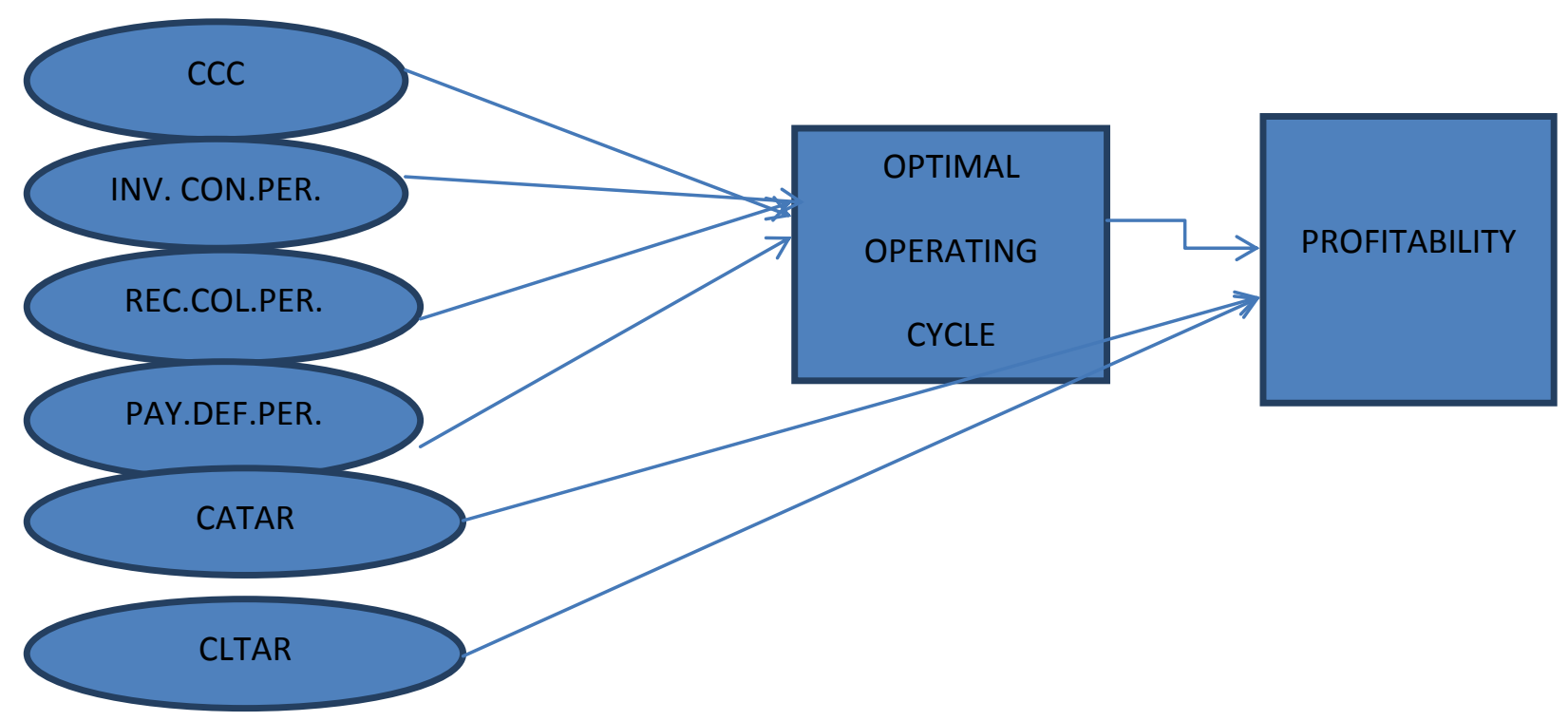

\section{Conclusion}

In conclusion, this paper has provided a theoretical framework which could be a reference model in investigating the relationship or impact of management of working capital and the profitability of manufacturing companies, especially in developing economies like Nigeria it provided a holistic approach to working capital measurement and introduce the intervening effect of optimal operating cycle of both profitability and Liquidity in ensuring the profitability of companies.

\section{References}

Afza, T. \& Nazir, M. S. (2007). Is it better to be aggressive or conservative in managing working capital? Journal of quality and technology management, 3(2), 11-21.

Akinbuli, S. F. (2006). Financial Accounting, Principles and Application, Lagos Blueprint Publishers

Ali, S. (2011). Working capital management and the profitability of the manufacturing sector. A case of Pakistan's Textile Industry. The Lahore Journal of Economic, 16(2), 141-178.

Brigham, E. C. \& Houston, M. (2007). Foundations Financial Management, Dryden Press Publishers.

Bringham E. F. \& Micheal, E. C. (1999). Financial Management Theory and Practice, Thomson southwester publishers. 159.

Deloof, M. (2003). Does working capital management Affect Profitability of Belgian firms? Journal of Business, Finance and Accounting, 30(3/4).

Demirguc, A. K. \& Huizinga, H. (2012). Profitability of Banks. The world Bank Economic Review Journal, 13(2).

Gill, A., Biger, N. \& Mathur, N. (2010).The relationship between working capital management and profitability. Evidence from the United States. Business and Economics Journal, 10, 1-9.

Howorth, G. \& Westhead, P. (2003). The focus of Working Capital Management in UK Small Firms. Management Accounting Research, 14(2), 94-111.

Lazaridis, I. \& Tryfonidis D. (2006). Relationship between Working Capital Management and Profitability of Listed Companies in the Athens stock exchange. Journal of Financial Management and Analysis, 19, 26- 35.

Nobenee, H. \& Alhajjar, M. (2012). Optimizing working capital management. Retrieved from: http://ssrn.com

Nor ediazhar, B. M. \& Noriza, B. M. S. (2010). Working capital management: the effect of market valuation and profitability in Malaysia. International Journal of Business and Management, 5(11).

Peavler, R. (2009). Cash Management is Important for Your Small Business Retrieved August22, 2012, from http://www.bizfinance.About.Com 1.odl cash management /a/ cash-mngt.on 16/5/2012.

Prasana, C. (2000). Financial Management. New Delhi: McGraw Hill Publishing Company. 
Raheman, A. \& Nasr, M. (2007). Working capital management and profitability-Case of Pakistani firms. International Review of Business Research Paper, 3, 279-300.

Richards, V. D. \& Laughlin, E. J. (1980). A cash conversion cycle approach to liquidity analysis. Financial management, 9, 32-38.

Shin, H. H. \& Soenen, L. (1998). Efficiency of working capital management and corporate profitability. Financial Practice and Education, 8(2), 37-45.

Smith, K. (1980). Profitability versus Liquidity trade -offs in working capital Management, in Readings on the Management of Working Capital New York: St. Paul west Publishingcompany.

Stanley, B. B. \& Geoffrey, A. H. (1997). Foundations of financial management. Irwin Publishers.

Talat, A. \& Nazir, M. (2011). Working management efficiency, of cement sector of Pakistan. Journal of Economics and Behavioral studies, 2, 223-235.

Uremadu, S. O., Egbide, B. C. \& Enyi, P. E. (2012). Working management, Liquidity and corporate profitability among quoted firms in Nigeria. Evidence from the Productive sector. International Journal of academic Research in Accounting, finance and management Science, 2(1).

Uwuigbe, O., Uwalomwa, U. \& Egbide, B. C. (2012). Cash management and corporate profitability; A study of selected listed manufacturing firms in Nigeria. ACTA universitatis Danibius, 8(1), 49-59.

Van Horne, J. C. \& Wachowicz, J. M. (2000). Fundamentals of financial management. Eleventh edition, prentice Hall Inc.

Wang, Y. J. (2000). Liquidity management, operating performance and corporate value: evidence from Japan and Taiwan. Journal of Multinational Financial Management, 12(2), 159-169.

Zainudin, N. (2006). Liquidity-profitability Trade-off: is it evident among Malaysians SMEs? International Journal of management, 13(2), 107-118. 